\title{
MEMBANGUN KOMUNIKASI DAN PENDIDIKAN \\ BERKARAKTER DALAM KELUARGA DALAM PENGENALAN AWAL ORGAN SEKSUAL PADA ANAK
}

\author{
Deni Nasir Ahmad \\ Pendidikan Matematika, Fakultas Teknik Matematika dan IPA, Uni versitas Indraprasta \\ PGRI \\ E-mail: deninasirahmad@gmail.com
}

\begin{abstract}
Childhood is the age to know many things, likes to do exploration, egoism and imitate people around him. Therefore, during the growth and development of children is expected parents continue to create and build communication to children. Creating and developing communication with children can be through children's play activities by including knowledge and character education in children. Character education in the family should be done so that children can be protected from acts that would endanger the child's sexual kekersan. Early recognition of the sexual organs in children must also be introduced by: 1 . Providing the correct information to the child in accordance with the reproductive device. 2. Provide information in accordance with the ability to think. 3 Taking into account the stage of development and growth of children on the basis of secondary characteristics of children. From the way to continue to build communication and character education in the family in the early introduction of sexual organs in children or childhood in the hope that children can avoid sexual violence behavior.
\end{abstract}

Kata kunci: Ko munikasi, Pendidikan Karakter, Organ Seksual, Usia Anak

Pemahaman orang tua akan pertumbuhan dan perkembangan anak harus dipahami mulai dari sebelum anak lahir sampai sesudah anak lahir. Pertumbuhan dan perkembangan anak perlu dideteksi oleh orang tua sejak dini. Menurut M. Solehudd in dan Ihat Hatimah (Maman dan Suparlan, 2014 : 27) anak memiliki karakteristik atau sifat-sifat berbeda dengan ciri pertumbuhan dan perkembangan lainnya yakni : memiliki sifat unik, egosentris, aktif dan berenergik, rasa ingin tau yang kuat dan berantusias, spontan, berfantasi, mudah frustasi, kurang pertimbangan, kurang perhatian, bergairah akan belajar dan pengalaman serta adanya keminatan dengan teman. Oleh karenanya perlu menciptakan komunikasi dua arah antara anak dan orang tua disebabkan karena anak memiliki karakter dan sifat yang khas.

Pemahaman orang tua terhadap tumbuh kembang anak perlu dilakukan dan dipahami oleh setiap orang tua terhadap anak-anak mereka, dikarenakan orang tua sebagai pembentuk dan pendidik karakter anak. Perlunya anak diberikan pendidikan karakter dalam keluarga disebabkan karena masyarakat Indonesia sudah luntur akan budaya leluhurnya, sebagai contoh : sudah tidak ada lagi sikap hormat antara anak dengan orang tuanya, murid dengan gurunya ataupun tidak adanya tenggang rasa antar sesama umat. Oleh karenanya anak harus diberikan hak alami yakni pendidikan, pengenalan agama, perlindungan, kesejahteraan dan lain sebagainya. 
Menurut UU No. 35 Tahun 2014 pasal 1 menjelaskan bahwa perlindungan anak adalah segala kegiatan untuk menjamin dan melind ungi anak dan hak-haknya agar dapat hidup, tumbuh, berkembang dan berpartisipasi secara optimal sesuai dengan harkat dan martabat kemanusiaan serta mendapat perlindungan dari kekerasan dan deskriminasi. Oleh karenanya pendidikan berkarakter dalam keluarga perlu dilakukan agar terhindar dari kekerasan dan deskriminasi pada anak. Pendidikan berkarakter dalam keluarga menurut Safrudin Aziz (2015 : 137) bertujuan untuk memberikan bekal akhlak yang baik kepada setiap anak untuk mampu berperilaku dan bersikap sesuai dengan aturan serta norma etika yang berlaku. Dari penanaman agama, aturan dan etika diharapkan anak dapat memahami tujuan dari pembentukan karakter pada dirinya.

Selain dari penanaman karakter kedua orang tua perlu mengenalkan organ reproduksi pada anak sejak anak mulai bisa diajak untuk berkomunikasi. Alasan mengapa kedua orang tua perlu mengenalkan organ reproduksi pada anak sejak awal atau dini adalah agar anak mengetahui apakah fungsi dari organ reproduksi tersebut dan kegunaanya organ reproduksi tersebut. Perlu diingat juga pemberian informasi haruslah sejalan dengan tumbuh dan kembang anak atau kemampuan berpikir anak. Dikarenakan bila pemberian informasi dari kedua orang tua atau salah satu orang tua tidak tepat memberikan informasi maka anak akan mengalami kebingungan bahkan salah mengekspresikannya. Contoh pemberian informasi yang salah dari orang tua : Anak laki-laki : "dede malu tau nanti burungnya bisa terbang loh kalo tidak ditutup". Seharusnya menyampaikan "dede Mr.P-nya ditutup dong jangan dibuka gituh". Kenapa harus menggunakan istilah Mr.P dikarenakan bahasa "Penis" untuk reproduksi laki-laki kita ganti agar bahasa pengenalan tidak terlalu jauh dari bahasa sebenarnya.

Adapun tujuan dari kajian ini adalah : 1). Memberikan informasi pentingnya membamgun komunikasi orang tua kepada anak melalui pengenalan awal organ reproduksi mereka. 2). Memberikan informasi pentingnya memberikan pendidikan berkarakter pada anak melalui pengenalan awal organ reproduksi mereka agar anak terhindar dari predator seksual anak.

\section{METODE}

Metode yang digunakan adalah kajian teori berupa pengambilan data dari kajian pustaka dan hasil penelitian yang telah dipublikasikan berupa jurnal. Adapun analisis data berupa deskripsi analisis dari hasil penelitian yang telah dipublikasikan.

\section{PEMBAHASAN}

1. Pertumbuhan

dan

\section{Perkembangan anak}

Pertumbuhan adalah bertambahnya tinggi badan, berat badan dan volume tubuh yang bersifat irreversible atau tidak dapat kembali lagi. Sedangkan perkembangan adalah bertambah dewasa pada seorang individu disertai dengan munculnya ciri sekunder pada diri individu tersebut. Menurut

Maman dan Suparlan (2014 : 1) perkembangan adalah suatu proses perubahan dalam diri individu atau organisme baik secara fisik (jasmaniah) maupun psikis (rohaniah) menuju tingkat kedewasaan atau 
kematangan yang berlangsung secara sistematis, progresif dan berkesinambungan. Maksud dari perkembangan secara : a. sistematis adalah perubahan dalam perkembangan itu bersifat saling ketergantungan atau saling memengaruhi antara bagian-bagian organisme (fisik dan psikis) dan merupakan satu kesatuan yang harmonis. Contoh : memperhatikan lawan jenis seiring dengan matangnya hormon seksual. b. progresif adalah perubahan yang terjadi bersifat maju, meningkat, mendalam atau meluas baik secara kunatitatif (fisik) maupun kualitatif (psikis). Contoh : perubahan pengetahuan dan kemampuan anak. c. berkesinambungan adalah perubahan pada bagian atau fungsi organisme tersebut berlangsung secara berurutan atau beraturan tidak terjadi secara kebetulan atau loncat-loncat. Contoh : Untuk mencapai dewasa harus melalui tahap anak-anak, remaja baru dewasa.

Pertumbuhan dan perkembangan pada usia anak memiliki karakter dan sifat berbeda dari tahap pertumbuhan lainnya sehingga pertumbuhan dan perkembangan pada usia anak terbagi atas (Maman dan Suparlan, 2014 : 31)

1. Periode awal usia anak (1-12 bulan)

Karakteristiknya :

a. Secara fisik, yaitu mulai mengangkat tubuh, merangkak, duduk dan berdiri, berjalan sendiri beberapa langkah.

b. Bahasa, yaitu menangis, mengoceh dan bereaksi ketika nama dipanggil

c. Daya cipta (kognigtif), yaitu mulai mengamati mainan, mengenal dan membedakan wajah ayah dan ibu, memasukan benda kedalam mulut.

d. Sosial-emosi, yaitu membalas senyuman orang lain, menangis sebagai reaksi tidak nyaman, tertawa dan menjerit karena gembira dan mengenal wajah anggota keluarga.

2. Periode usia anak/batita (1-3 tahun)

Karakteristiknya :

$\begin{array}{lr}\begin{array}{l}\text { a. Secara fisik, } \\ \text { mengambar } \\ \text { sederhana, }\end{array} & \begin{array}{r}\text { yaitu } \\ \text { bentuk }\end{array} \\ \text { mencoba }\end{array}$

memanjat, berjalan lancar.

b.Bahasa, yaitu mengucap kalimat dari dua kata, dapat menggunakan bahasan isyarat, mengerti perintah sederhana, dapat menyebut namanya sendiri, dapat mengeluarkan kalimat tanya, mengerti bahasa larangan.

c. Daya cipta (kognigtif), yaitu mulai mengenal benda sendiri, mulai mengenal konsep warna dan bentuk, meniru perbuatan orang lain, menunjukkan rasa ingin tau yang besar, mengenal makhluk hidup.

d. Sosial-emosi, yaitu dapat berinteraksi dan berkomunikasi dengan anggota keluarga yang dikenal, menunjukan reaksi emosi yang wajar (marah, nangis, sakit, takut).

e. Seni, yaitu dapat bertepuk tangan, mengikuti gerakkan sesuai irama, bernyayi dengan bimbingan orang tua dan guru.

f. Moral-spiritual, yaitu dapat mengucapkan doa-doa pendek, dapat mngikuti gerakan-gerakan ibadah.

3. Periode anak-anak (4-6 tahun) 
Karakteristiknya :
a. Secara fisik, yaitu dapat berjalan dengan cepat, melompat, dapat bangun dan tidur sendiri, menggunting, melipat kertas.

b. Bahasa, yaitu menyebutkan (nama, jeniskelamin, umur dan alamat), berbicara lancar tapi masih sederhana, senang mendengar dan menceritakan kembali cerita sederhana.

c. Daya cipta (kognigtif), yait u dapat mengkelompokkan benda, dapat berhitung dan mengukur, dapat menggunakan waktu.

d. Sosial-emosi, yaitu bekerjasama, tenggang rasa, dapat bermain atau bergaul dengan teman, mulai belajar berpisah dari orang tua, mengenal dan mengikuti aturan.
e. Seni, yaitu dapat menggambar, menganya $\mathrm{m}$ sederhana.

\section{Peran Orang Tua Pada Keluarga \\ Karakter dan sifat} pertumbuhan dan perkembangan usia kanak-kanak adalah usia ingin mengetahui banyak hal, suka melakukan eksplorasi, egoisitas dan meniru orang sekelilingnya. Oleh karena itu pada masa pertumbuhan dan perkembangan anak diharapkan orang tua terus menciptakan dan membangun komunikasi kepada anak. Menciptakan dan mengembangkan komunikasi dengan anak bisa melalui kegiatan bermain mengikuti anak dengan memasukan pengetahuan dan pendidikan karakter pada anak. Menurut Safrudin Azis (2015 : 47) menjelaskan bahwa pendidikan usia kanak-kanak memerlukan pemikiran, perjuangan, kesungguhan serta motivasi yang kuat dari setiap orang tuanya. Oleh karena itu perlunya orang tua terus memantau pertumbuhan dan perkembangannya.

Perlunya orang tua terus memantau pertumbuhan dan perkembangan anak disebabkan karena banyaknya permasalahan yang sering terjadi pada anak sehingga perlu diadakan pendidikan berkarakter. Permasalah tersebut diantaranya yaitu : a. pengaruh perkembangan globalisasi dimaksudkan bahwa kemudahan memperoleh informasi melalui kecanggihan teknologi. Kecanggihan teknologi ini terkadang membawa permasalah bagi para penggunanya dizaman sekarang terutama bagi tahap perkembangan anak yakni anak menjadi bersifat individualisne, asik terhadap dunianya sendiri, tidak mudah bergaul atau minder dengan teman-temannya. b. pengaruh perkembangan regional dimaksudkan bahwa anak harus diberikan perlindungan dan pelayanan kebutuhan anak seperti : hak memperoleh pendidikan, kesehatan, perlindungan dan kesejahteraan anak. c. pengaruh perkembangan nasional, yaitu dimaksudkan bahwa banyaknya kekerasan fisik, kekerasan seksual dan kekerasan secara sikis yang sering dialami oleh anak. Oleh sebab itu perlunya perlindungan hukum atas permasalahan yang sering terjadi agar anak merasa nyaman memperoleh haknya (Titik Haryati, 2017 : 82-87).

Dari permasalahan tersebut jelas bahwa peran orang tua dalam keluarga sangat besar terutama dalam melindungi, mendidik, merawat dan memberikan kesejahteraan pada anak. Dari tugas utama orang tua tersebut diharapkan anak terjaga, terawat dan terlindungi dari hal-hal yang merugikan anak seperti kekerasan fisik dan kekerasan seksual pada 
anak. Adapun antisipasi yang mungkin dapat dilakukan adalah sebagai berikut :

a. Membangun Komunikasi. Komunikasi perlu dilakukan antara orang tua dengan anak agar adanya ikatan batin antara keduanya. Selain itu membangun komunikasi orang tua dengan anak bertujuan agar informasi-informasi yang diberikan orang tua terhadap anaknya bisa langsung disampaikan. Menurut Laswell (Winarti, 2012 : 70) komunikasi digambarkan dalam ungkapan "who says what in which channel to whom with what effect." Siapa mengatakan apa dengan saluran (sarana), apa kepada siapa dengan pengaruh bagaimana. Siapa merupakan sumber atau komunikator, memberikan suatu pesan melalui suatu alat (sarana) kepada penerima yang memberikan dampak seperti bertambahnya pengetahuan. Selanjutnya menurut Ambarjaya (2012 : 111) bahwa, "komunikasi adalah penyampaian dan memahami pesan dari satu orang kepada orang lain, komunikasi merupakan proses sosial".

$$
\text { Dari hasil penelitian }
$$
Martia,dkk dalam jurnal publikasi, hal. 124 mengenai komunikasi orang tua terhadap anak mengenai perkembangan reproduksi anak remaja adalah sebagai berikut : berdasarkan hasil perolehan data diperoleh nilai t-Hitung sebesar 3,733.oleh karna hasil uji t statistik (t. Hitung) lebih besar dari nilai $t_{\text {-Tabel }}$ ($3,733>1,9977)$ atau probabilitas $t$ lebih kecil dari $0,005(0,000<0,005)$ maka $\mathrm{H}_{0}$ ditolak pada taraf signifikan 0,05 . Artinya bahwa variabel kualitas komunikasi orang tua dan anak $\left(\mathrm{X}_{2}\right)$ mempunyai hubungan yang signifikan dengan perilaku seks bebas (Y). Hal ini berarti hipotesis kedua yang menyatakan bahwa "Terdapat hubungan antara kualitas komunikasi orang tua dan anak dengan perilaku seks bebas pada remaja siswa-siswi MAN Gondangrejo Karanganyar" terbukti. Selajutnya dari hasil penelitian Berdasarkan hasil dari penelitian Sarah, hal 9 yakni komunikasi interpersonal orang tua dan siswa SMA Negeri 12 Medan kelas $\mathrm{X}$ dan XI tentang kesehatan reproduksi sudah berjalan dengan baik. Walau masih terdapat beberapa siswa yang masih merasa malu, segan, dan tidak sopan untuk berkomunikasi tentang kesehatan reproduksi, namun mayoritas siswa sudah memiliki sikap yang terbuka dengan orang tua. Selain itu, terdapat beberapa siswa yang orangtuanya cenderung menaruh curiga dan memaksakan kehendak

Dari pendapat tersebut jelas bahwa komunikasi sangat dibutuhkan oleh setiap individu terutama antara orang tua dengan anak-anak mereka. Komunikasi antara anak dan orang tua bisa dilakukan di beberapa kesempatan misalkan bersama anak dan orang tua menonton televisi secara bersama di ruang keluarga ataupun sambil berolahraga bersama. Membangun komunikasi antara anak dan orang tua sangat penting guna membangun rasa kebersamaan, tenggang rasa, sikap menghormati dan menciptakan kedekatan anak dengan orang tua. Dengan membangun komunikasi antara anak dan orang tua diharapkan anak tidak frustasi atas masalah-masalah yang dihadapi sehingga orang tua dapat mengontrol dan mengetahui permasalahan yang dihadapi oleh anak-anak mereka.
b. Pendidikan Berkarakter Dalam Keluarga Pendidikan berkarakter dimaksudkan adalah sebuah proses


pendidikan yang dilakukan untuk membentuk perilaku atau watak seseorang sehingga seseorang mampu memahami, merasakan, membedakan sekaligus menerapkan perbuatan atau sikap yang baik dan yang buruk tersebut dalam segala aspek kehidupan (Safrudin Aziz, 2015 : 132). Menurut UU Sistem pendidikan nasional (Sisdiknas) tahun 2003 mengamanatkan agar pendidikan membentuk insan Indonesia yang cerdas dan berkepribadian atau berkarakter, sehingga diharapkan akan lahir generasi bangsa Indonesia yang cerdas dan berkarakter. Selanjutnya pendidikan karakter dalam agama islam adalah terwujudnya manusia yang bertaqwa kepada Allah Swt. Berdasarkan hasil telah jurnal oleh abd. Mukhid (Nuansa, 2016 : 326) menyimpulkan bahwa : 1. Perintah untuk berbuat baik (ihsan), dan kebajikan (al-birr), menepati janji (al-wafa), sabar, jujur, takut kepada Allah SWT, bersedekah di jalan Allah, berbuat adil, pemaaf dalam banyak ayat didalam al-Quran, diantaranya seperti di dalam AlQur'an surat An-Nahl ayat 90, dan surah al-Isra' ayat 23-24. 2.Prinsipprinsip dan nilai karakter mulia yang harus dimiliki oleh setiap pribadi muslim.Pendidikan Islam sejak awal menekankan agar nilai-nilai pendidikan karakter ditanamkan kepada anak sejak dini, yaitu: (a) memberikan Keteladanan, membiasakan peserta didik untuk konsisten dalam beribadah dan beramal sholeh, (c) memberikan pendidikan tentang kesadaran tentang prinsip-prinsip dan dasar-dasar akhlak, (d) menanamkan sikap, perilaku, dan tutur kata yang mulia kepada peserta didik.

Dari keterangan tersebut jelas bahwa betapa pentingnya penanaman pendidikan karakter pada anak agar tercipta generasi-generasi yang unggul serta percaya adanya Tuhan YME. Oleh karena itu pendidikan karakter dimulai dari dalam keluarga yakni orang tua sebagai pendidik awal sebelum anak masuk kedalam sekolah dan lingkungan masyarakat. Pendidikan karakter dalam keluarga sangat penting dilakukakan hal ini dikarenakan : a. karakter bangsa berdasarkan ketuhanan YME. b. karakter bangsa yang saling menghormati satu dengan lainnya. c. sistem pendidikan di Indonesia berlandaskan atas pendidikan berkarakter. d. merupakan kewajiban kedua orang tua mengenalkan agama sebagai pendidikan karakter karena setelah orang tua meninggal hanya do'a dari anak keturunan mereka meringankan dosa orang tuanya. e. penangkalan perkembangan zaman dan teknologi agar anak dapat terbentengi dari perilaku yang buruk (Titik Haryati, 2017 : 82). Pendidikan karakter seperti apa yang dilakukan oleh orang tua terhadap anak-anaknya yaitu : a. penanaman agama, norma dan moral. b. mengenalkan karakter bangsa dan masyarakat yang religius. c. pola pergaulan dan perilaku hubungan antar teman sebaya serta orang tua dengan usia muda (Safrudin Aziz, 2015).

c. Mengenalkan Organ Seksual Yang Dimiliki Oleh Anak.

Perlunya mengenalkan organ seksual yang dimiliki oleh anak merupakan salah satu cara pencegahan tindak kekerasan seksual pada anak. Berdasarkan hasil survei yang dilakukan oleh Komisi Perlindungan Anak Indonesia menemukan banyak aduan kekerasan pada anak pada tahun 2010. Dari 171 kasus pengaduan yang masuk, sebanyak 67,8 persen terkait dengan kasus kekerasan. Dan dari kasus kekerasan tersebut yang paling 
banyak terjadi adalah kasus kekerasan seksual yaitu sebesar 45,7 persen (53 kasus). Komisi Nasional Perlindungan Anak (Komnas Anak) mencatat, jenis kejahatan anak tertinggi sejak tahun 2007 adalah tindak sodomi terhadap anak. Dan para pelakunya biasanya adalah guru sekolah, guru privat termasuk guru ngaji, dan sopir pribadi. Tahun 2007 jumlah kasus sodomi anak, tertinggi di antara jumlah kasus kejahatan anak lainnya. Dari 1.992 kasus kejahatan anak yang masuk ke Komnas Anak tahun itu, sebanyak 1.160 kasus atau 61,8 persen, adalah kasus sodomi anak. Dari tahun 2007 sampai akhir Maret 2008, jumlah kasus sodomi anak sendiri sudah naik sebesar 50 persen (24 Juni 2016, https://loveindonesiachild ren.wordpre ss.com).

Berdasarkan hasil survei tersebut jelas bahwa betapa pentingnya mengenalkan organ seksual yang dimiliki oleh anak, dikarenakan pada usia perkembangan ini sangat rentan terhadap tindak kekerasan seksual. Oleh sebab itu orang tua perlu memperkenalkan organ seksual pada anak dengan memperhatikan hal sebagai berikut :

a. Harus dilakukan oleh orang terdekat. Dalam mengenalkan anak mengenai organ seksual perlu adanya pendekatan kepada anak orang yang paling dekat dengan anak adalah orang tua. Dalam prosesnya, orang tua harus komunikatif, rendah hati dan mau mendengarkan apa yang ditanyakan oleh anak.

b. Disesuaikan dengan daya tangkap anak. Dalam mengenalkan organ seksual pada anak perlu diperhatikan daya tangkap anak agar anak dapat memperoleh informasi secara maksimal. c. Pemantauan terus menerus Pemantauan perlu dilakukan dikarenakan orang tua harus tau kapan anak mengalami perubahan fisik secara seksual yaitu saat anak mengalami menstruasi atau mimpi basah, orangtua harus menjadi sahabat yang baik. Dengan menjadi sahabat, orangtua lebih mudah mengingatkan kembali fungsi alat kelamin dan tidak menggunakannya sembarangan.

d. Segamblang mungkin Seks sebaiknya dijelaskan segamblang mungkin kepada anak. Dengan penjelasan yang benar dan menyeluruh, anak tidak akan berimajinasi atau memiliki sudut pandang sendiri. Penjelasan yang tidak utuh justru akan memancing rasa penasaran anak. Untuk memulai suatu penjelasan pancing anak seberapa besar pengetahuan anak tentang seksual mereka. (Seto Mulyadi, 31 agustus 2015. www. Kompas.com)

Senada dengan pendapat tersebut menurut Inneke Limuria menjelaskan bahwa dalam mengenalkan organ seksual pada anak orang tua tidak perlu menggunakan istilah lain untuk menyebut organ genital laki-laki ataupun organ genital perempuan, biasakanlah gunakan bahasa organ seksual tersebut dengan namanya, misalkan Mr.P atau Miss. V (2 Desember 2013, detik health.com). Dari pendapat tersebut jelas bahwa mengenalkan organ reproduksi pada anak perlu dilakukan dengan cara pendekatan komunikasi informatif, gunakan istilah yang seharusnya, sesuai dengan kemampuan berpikir anak dan terus memperhatikan 
tahap perkembangan anak dengan memperhatikan hal tersebut diharapkan orang tua dapat memaksimalkan pendidikan seksual pada anak.

Adapun langkah-langkah memperkenalkan organ seksual pada anak adalah sebagai berikut :

1. Ajak anak mengenali bagian tubuhnya dan jelaskan fungsi setiap bagian dengan bahasa sederhana. Katakan bahwa tubuhnya adalah karunia yang sangat berharga dan harus dijaga dengan baik.

2. Bangun kebiasaan positif misalnya, tidak berganti baju di tempat terbuka, tidak pipis di sembarang tempat, dll.

3. Tanamkan pentingnya menjaga organ tubuh tertentu, seperti alat vital, dari sentuhan orang lain. Tentu saja disertai penjelasan sederhana yang bisa ia terima dan mengerti dengan baik.

4. Biasakan anak berpakaian sesuai identitas kelaminnya sejak dini. Banyak kelalaian orang tua untuk hal ini. Mereka membuat anak perempuan menjadi tomboy dan anak laki-laki menjadi feminin. Dalam kondisi ekstrem anak bahkan bisa mengalami kebingungan identitas seksual. Clara Kriswanto (www.parenting.co.id)

\section{KESIMPULAN}

1. Membangun komunikasi antara orang tua dan anak perlu dilakukan dalam mengenalkan awal organ seksual pada anak agar anak memahami merawat dan menfungsikan organ reproduksi yang dimilikinya.

2. Pendidikan karakter yang diberikan orang tua kepada anak dalam kelurga perlu dilakukan dalam mengenalkan awal organ seksual pada anak agar anak dapat membentengi diri apabila terjadi tindakan seksual.

\section{SARAN}

1. Orang tua terus ikuti perkembangan seksual anak dengan cara ajak komunikasi dan pendidikan karakter terus dibangun dan di tingkatkan

2. Perlu adanya aturan yang jelas kepada pemerintah mengenai lingkungan aman dan ramah anak agar anak bisa tumbuh dan berkembang.

\section{DAFTAR RUJUKAN}

Achdiyat, Maman, Kasyadi, Soeparlan. 2014.

Perkembangan Peserta Didik. Unindra Press : Jakarta.

Ambarjaya, Beni S., 2012. Psikologi Pendidikan dan Pengajaran Teori dan Praktik. CAPS : Yogyakarta.

Aziz, Safrudin. 2015. Pendidikan Keluarga Konsep dan Strategi. Gava Media: Yogyakarta.

Haryati, Titik. 2017. Perlindungan Anak (Kejahatan Kekerasan Seksual dan Disabilitas/Autis dengan Model Bimbingan Tingkah Laku). PTIK : Jakarta.

Winarti, Euis.

Pengembangan

Kepribadian. Jakarta: Lentera Ilmu Cendekia.

Love Children, Mahasiswa Penyayang Anak. Angka Kejadian Kekerasan Seksual Di Seluruh Dunia. 
24 Juni 2016, https://lo veindonesiachild re n.wordpress.com. Diakses 31 Juli 2017.

Mulyadi, Seto. 4 Cara Mengenalkan Seks Edukasi pada Anak. 31 Agustus 2015. www. Kompas.com.

Diakses 31 Juli 2017

Limuria, Inneke. Pendidikan Seks Usia Dini Kenalkan Organ Reproduksi pada Anak, Lewat Gambar atau Tunjuk Langsung?. 2 Desember $2013 . \quad$ www. health.detik.com. Diakses 31 Juli 2017

Kriswanto, Clara. Cara Mengenalkan Seks Pada Balita.

www.parenting.co.id.

Diakses 31 Juli 2017

Mukhid Abd., Konsep Pendidikan Karakter Dalam Al-Qur'an. Nuansa, Vol. 13 No. 2 Juli Desember 2016. 